\title{
EDITORIAL \\ Value of children in our world
}

Pediatric Research (2022) 92:1202-1203; https://doi.org/10.1038/ s41390-021-01609-0

The Sandy Hook, Dayton, and El Paso mass killings have all involved children being victims of violence or losing their parents. It's not difficult to infer the subsequent lack of gun control essentially means that the public have accepted the murder and suffering of children. This is more than social media rhetoric; children continue to be separated from their parents and/or family members at our borders, and the ongoing practice of separating children from relatives or siblings, while familial ties are validated can take weeks to months. This is not a north American phenomenon as the ongoing plight of Syrian and Libyan refugees demonstrates. As practicing pediatricians and neonatologists, we are enraged that our countries and world, accepts these events happening to children. Why is a principle of zero tolerance not applied to these tragedies, as it is in Sweden to road deaths? (https://www.york.ac.uk/news-and-events/news/2006/ zero-tolerance/).

Thus, the question thus arises about the value of children in society. Two decades ago, the Institute of Medicine published a book on the impact of the environment on children, Children's Health, the Nation's Wealth. ${ }^{1}$ In it is the following sentence on how our societies value our children: "The social transformation of childhood in modern societies reflects a retreat from the view that parents have full and unlimited jurisdiction over their children to one, in which the welfare of children is increasingly understood as a shared social responsibility, which requires investments in education, health care, and other institutions." Those other institutions may be seen to be institutions engaged in research that assesses and improves child health, both for the child and for the adult the child will become.

From this sentence quoted above, ${ }^{1}$ it seems as though the value of our children to society has steadily risen over the past few centuries, ${ }^{1,2}$ since the rights of the child were enshrined in the United Nations convention. ${ }^{3}$

But it seems now that we are in a downward spiral. That the value of children depends on whose child. That the value of children depends on their ethnicity, the wealth of their parents, their genetic makeup, and their socioeconomic level. For example, the infant mortality rate in the US is higher among Black non-Hispanic infants, Native American infants, and Hispanic infants than white non-Hispanic infants (https://www.childstats.gov/americaschildren/infant_mortality. asp). Another example is the higher adolescent birth rates in Black non-Hispanic, Native American non-Hispanic, and Hispanic girls than white girls (https://www.childstats.gov/americaschildren/births.asp). In the UK, adolescent pregnancies were highest in Black Caribbean and White British women (https://www.ons.gov.uk/peoplepopulationand community/healthandsocialcare/causesofdeath/bulletins/pregnancy andethnicfactorsinfluencingbirthsandinfantmortality/2015-10-14\#ageof-mother-at-birth-of-baby). While the total infant mortality rate is lower in the United Kingdom, racial disparity still exists with an infant mortality rate of 54.1 deaths per 1000 live births of babies born to Black African parents compared to Indian, White British, White Other, and other ethnic groups (24.3, 29.0, 32.5, and 33.0, respectively; https:// www.ons.gov.uk/peoplepopulationandcommunity/healthandsocial care/causesofdeath/bulletins/pregnancyandethnicfactorsinfluencingb irthsandinfantmortality/2015-10-14\#: :text=Babies\%20of\%20Black\% 20African\%20origin,29.0\%2032.5\%20and\%2033.0\%20respectively).

This devaluation of children has also negatively impacted the support that research affecting children has received. Within the National Institutes of Health, the largest funder for pediatric research, the funds allocated to pediatric research is $<10 \%$ of the total budget ${ }^{4}$ (https://www.nih.gov/about-nih/what-we-do/ budget), hardly representing the makeup of the population of the United States, where $22 \%$ of the population is $<18$ years of age. ${ }^{5}$ In addition, the average annual growth rate in the amount of money going to the support of pediatric research has declined from $12.8 \%$ (FY 1998-2003) to 1.7\% (FY 2004-2015). ${ }^{6}$ This is similar to the situation in the European Union with an ongoing need to lobby the European Commission and national governments about the priorities and key messages for children. ${ }^{7}$

As part of a society that values children, we need to champion the ongoing research into all aspects of their growth and development. But just championing research is not enough, to what end will this research produce if underlying policies and attitudes undermine it? We, as pediatricians, need to influence our leaders. We need to have demonstrable impact. I would call on the leaders of our societies to make this impact with the support of our societies' members. Initial strategies might be campaigning from all of us to our representatives in Congress, the Senate, and the Executive Office. Making our voices heard through editorials, social media, society messages, and writing policy commentaries much like those on guns ${ }^{8}$ or tobacco. ${ }^{9}$ However, as letter writing is easily ignored, collaborating with those advocating for all children is an objective and morally defensible action.

Pediatricians as a group have worked hard to discover and implement interventions and cures for childhood diseases. Our next effort must be directed, not at a biomedical aim, but a social one. It is time to work together and stop the murder of children.

\section{ADDITIONAL INFORMATION}

Competing interests: The authors declare no competing interests.

Publisher's note Springer Nature remains neutral with regard to jurisdictional claims in published maps and institutional affiliations.

Cynthia F. Bearer ${ }^{1}$, Damian Roland ${ }^{2}$ and Eleanor J. Molloy ${ }^{3}$

${ }^{1}$ Division of Neonatology, Department of Pediatrics, $R B C$, Case Western Reserve University School of Medicine, Cleveland, $\mathrm{OH}$, USA; ${ }^{2}$ University of Leicester, Health Sciences Medical Centre, Leicester, UK and ${ }^{3}$ Paediatrics, Trinity College, the University of Dublin, Dublin,

Ireland

Correspondence: Cynthia F. Bearer (Cynthia.Bearer@uhhospitals.org)

\section{REFERENCES}

1. National Research Council (US), Institute of Medicine (US). Children's Health, The Nation's Wealth: Assessing and Improving Child Health, 29 (National Academies Press, 2004).

2. Zelizer, V. A. Pricing the Priceless Child: The Changing Social Value of Children (Princeton University Press, 1994). 
3. Molloy, E. J. Dr Janusz Korczak: paediatrician, children's advocate and hero. Pediatr. Res. 86, 783-784 (2019).

4. NIH Pediatric Research Consortium (N-PeRC) | NICHD - Eunice Kennedy Shriver National Institute of Child Health and Human Development. www.nichd.nih.gov/ research/supported/nperc (2021).

5. United States - Population under 18 years, percent by State. indexmundi.com (IndexMundi, 2021).

6. Gitterman, D. P., Langford, W. S. \& Hay, W. W. Jr. The uncertain fate of the National Institutes of Health (NIH) pediatric research portfolio. Pediatr. Res. 84, 328-332 (2018).
7. Molloy, E. J., Modi, N., Greenough, A., Lagercrantz, H., Bearer, C. F. \& Turner, M. The future of pediatric research: European perspective. Pediatr. Res. 81, 138-139 (2017).

8. Addressing gun violence. https://publications.aap.org/aapnews/news/6738 (2016).

9. American Academy of Pediatrics. Clinical practice policy to protect children from tobacco, nicotine, and tobacco smoke. https://publications.aap.org/pediatrics/ article/136/5/1008/33904/Clinical-Practice-Policy-to-Protect-Children-From (2015). 